\title{
The Political Economy of Exchange Rate Policy-Making
}

\author{
Steven Kettell \\ Department of Politics and Intemational Studies \\ University of Warwick \\ Coventry \\ CV4 7AL
}

This paper is released under the terms of the GNU Free Documentation License.

For more information see http://www.gnu/licenses/fdl.txt

This article critically examines existing theoretical perspectives on the political economy of exchange rate policy-making, and develops an alternative approach based on an 'open Marxist' methodology. It argues that exchange rate policy-making needs to be analysed as a component part of a wider governing strategy developed by state managers to provide favourable conditions for capital accumulation, regulate class struggle, and ensure sufficient autonomy for the pursuit of high political goals.

\section{Introduction}

As the set of institutional arrangements, mechanisms, and tools that are used to influence or control the value of the national currency on the foreign exchange markets, an 'exchange rate regime' forms one of the principal means by which a national state is integrated into the global economy. The process of exchange rate policy-making, therefore, is of far-reaching importance for a wide variety of national and international factors, ranging from levels of economic output, employment, prices and trade, to political relations both within and between states. This point is perfectly illustrated by the evolution of the international monetary system itself. The fixed exchange rate regime enshrined in the nineteenth century 'classical' gold standard helped to impart an unprecedented level of economic and political stability to its participants prior to its collapse during the First World War, while the flawed attempt at reconstructing the regime, followed by a renewed collapse during the 1920s and 1930s, played an intimate role in the instability and chaos which characterised this period. In a similar fashion, the establishment of the Bretton Woods system of fixed-but-adjustable exchange rates after the Second World War provided the lynchpin for renewed stability and presided over the greatest boom in the history of global capitalism, while the eventual disintegration of this regime from the late 1960s was also accompanied by the onset of a severe global recession and rising political unrest. Moreover, while events since the demise of Bretton Woods have witnessed a shift to more eclectic monetary arrangements, and to an international monetary system that combines a variety of fixed, managed, and floating regimes, the impact of exchange rate policy-making nonetheless remains keenly felt. Some of the more notable examples of this have been evidenced in the recent currency crises which engulfed large parts of 
Asia and Latin America during 1997-1998, and the politically and economically fraught progression of the drive towards monetary union in Western Europe.

Despite the obvious importance of this subject for an understanding of high-level political and economic developments, the question of exchange rate policy-making has received scant attention from radical political economists. The central purpose of this article is to start redressing the balance. Structured in three main parts, the article begins with an outline and a critique of existing theoretical approaches to this issue before constructing an alternative framework of analysis based on an 'open Marxist' methodology. This enables the process of exchange rate policy-making to be seen as a component part of a wider governing strategy that is designed by state managers with a view to ensuring favourable conditions for capital accumulation, containing class struggle, and providing sufficient autonomy for the pursuit of high political goals. On this basis, the final section of the article summarises the relative advantages and disadvantages that are offered by the various types of exchange rate regime. The paper begins then, by examining the existing theoretical approaches to the subject of exchange rate policy-making (for a more comprehensive analysis of these issues see Kettell 2004).

\section{Theories of exchange rate policy-making}

In broad terms, the existing theoretical literature on exchange rate policy-making can be divided into three main schools of thought. These are the 'rational choice', the 'country characteristics', and the 'interest group' approaches. The first of these theoretical perspectives, the 'rational choice' approach, is by far the most common (examples include Helpman 1981; Cuckierman and Meltzer 1986; Hamada 1987; Miller et al 1989; Bordo and Kydland 1995). This provides an analytical model based on a series of interactions between equally rational, self-maximising groups of public and private actors, and views exchange rate policy-making as part of an attempt by the public authorities to establish a credible, anti-inflationary 'policy rule'. While a discretionary regime which permits the authorities to continually adjust policies in response to changing circumstances is believed to present officials with an inherent temptation to use inflationary measures in order to stimulate economic growth and political popularity, a regime which credibly binds future economic policy decisions to an anti-inflationary rule (such as a set target for the growth of the money supply) is thought to produce more optimal long-term outcomes in terms of economic performance and political stability by constraining the expectations, and hence the price- and wage-setting behaviour of market actors.

Translated into exchange rate policy-making, this approach primarily contends that the most credible, and hence the most optimal policy rule, is provided by a fixed exchange rate regime. A publicly stated commitment to maintain a specified value for the national currency is believed to impose a clearly visible constraint on the economic policy-making behaviour of the authorities (since this will now need to be subordinated to ensuring this end), while the high costs of reneging on the commitment in terms of international recriminations and a loss of trustworthiness are thought to ensure a high degree of credibility. At the same time though, there remains no consensus between rational choice theorists on this issue, and others have argued that a floating, rather than a fixed exchange rate regime, will provide the most optimal policy rule. Since this will allow the value of the national currency to be determined directly by the market, and since movements in the exchange rate will now provide a clear, quick, and forceful signal to private actors as to whenever inflation is emerging, the threat of a large fall in the exchange rate is thereby believed to constrain 
the behaviour of the authorities, duly forcing them to maintain a sound economic policy stance. As a result, by claiming that both floating and fixed exchange rate regimes are capable of providing an optimal policy rule, though by offering no grounds for choosing between them purely on the basis of rational choice, this approach remains ambiguous and inconclusive, and its utility as a means of analysing exchange rate policy-making is therefore diminished.

In contrast, the second perspective, known as the 'country characteristics' approach, argues that exchange rate policy is not made with a view to avoiding the problems of discretionary economic management, but that it is technocratic decision based on a cost-benefit analysis of all the available options. The idea of a single 'optimal' policy is thus replaced by the notion that policy-makers will shift between exchange rate regimes in response to changing circumstances in order to achieve their policy goals (see for example Argy 1982, 1990; Savvides 1990; Aghevli and Montiel 1991; Honkapohja and Pikkarainen 1994; Edwards 1996; Oatley 1997; Caramazza and Aziz 1998). The key variables involved in this decision are considered to be the particular structural features of the country in question. Among the various relevant factors, some of the more notable are thought to be the size and openness of a country's economy, its degree of economic flexibility, and the geographical pattern of its international trade. One commonly held view, for instance, is that countries with small and open economies, rigid economic structures, and/or who possess extensive links with a large trading partner will prefer a fixed or tightly managed exchange rate regime as a defence against economic uncertainty and currency instability, while countries with large and relatively closed economies, who have more flexible economic structures, and/or who have no suitable trading partner with whom to stabilise their exchange rate will prefer a floating regime in order to maximise their domestic freedom of manoeure.

In addition to these economic factors, the political structure of a country is also believed to have an important influence. In particular, the relative strength and stability of the government in comparison to its main opposition party is believed to be a key causal variable. As a general rule, weak and unstable governments facing strong political opposition are thought to prefer a floating rather than a fixed exchange rate regime, since the latter will not only allow the opposition to bolster their economic policy credibility by committing themselves to continuing with the same system, but will also prove to be electorally damaging should the government be forced to abandon it. Fixed exchange rate regimes then, are considered more likely to be adopted by stronger governments, since these will be better placed to defend it and to weather any political storms that may subsequently arise (see Milesi-Ferretti 1995).

As with the rational choice approach, however, a central problem with the country characteristics approach is that there is no consensus between its proponents as to the precise causal mechanisms at work. In particular, there is no agreement as to which particular characteristics, or combination of characteristics, are the most important in the policy-making process. In direct opposition to the more generic views outlined above, adherents to this perspective have also argued that countries with small, open economies, or rigid economic structures, will prefer a floating rather than a fixed exchange rate regime on the grounds that exchange rate flexibility will help to insulate the domestic economy from the constraints of its external environment, and have claimed that weak governments will prefer fixed rather than floating exchange rate regimes since this can help to strengthen their economic policy credibility. Against this backdrop then, with no apparent means of determining which factors are the most influential, the country characteristics approach must also be regarded as having a limited explanatory value. 
In contrast to both these approaches, the final theoretical perspective on exchange rate policymaking, the 'interest group' approach, argues that the key factors involved are the relative balance of power between various socio-economic interest groups and sectors, combined with their respective degree of political organisation and interaction with the policy-making process (see for example Vaubel 1990; Havrilevsky 1994; Walsh 1994, 2000; Hefeker 1997; Frieden 1998, 2000). This approach is based on the notion that different groups and sectors will possess differing exchange rate preferences according to the nature of their business and the degree to which they are exposed to global competition, and claims that the interests of the dominant group (or groups) will invariably determine the policy to be adopted by the government. In relation to this, it is commonly argued that groups which are strongly oriented towards the global market will favour a fixed exchange rate regime in order to reduce the risks involved during the course of their business, while groups whose activities are more heavily weighted towards the domestic market will favour a floating regime since this will allow the authorities to adjust economic policy according to changing circumstances. In addition to this, it is also generally argued that groups whose business activities involve a high level of foreign purchases will prefer a relatively high exchange rate, since this will reduce the cost of their acquisitions, while groups that are engaged in direct competition with foreign producers will favour a depreciated exchange rate, since this will raise the domestic price of imported goods and will thereby increase the relative competitiveness of their products.

Along with the previous schools of thought, however, the interest group approach is also subject to several difficulties. One key problem, for example, is that yet again there is no consensus among its proponents as to the key causal mechanisms involved. Opinions remain divergent about which economic sectors are the most influential, and which will be best positioned to realise their demands through the political system, while it is also unclear precisely how competing preferences are reconciled within the political process itself. Moreover, the interest group approach does not adequately account for the fact that policy-makers themselves may have interests, and that these may be in opposition to those of the dominant group. The assumption that exchange rate policy will simply reflect the preferences of the strongest organisation or sector is problematic, since it is wholly implausible that policy-makers will be able to overlook the wider political and economic ramifications of exchange rate policy, especially if these prove to be of a detrimental nature. In this context, the analytical benefits of the 'interest group' approach must also be called into question (on these points also see Oatley 1997, pp.16-18).

\section{An 'open Marxist' approach}

In addition to their particular shortcomings, the theoretical approaches to exchange rate policymaking examined above are also problematic on more general methodological grounds. One major difficulty here derives from the positivist ontology on which such approaches are constructed. Since this holds that only directly observable phenomena can have any real and substantive existence, the starting point for analysis is inevitably located in the immediate perceptions of social reality, which is seen to be composed of a multitude of discrete 'components', such as separate 'public' and 'private' spheres, 'political' and 'economic' structures, and sectorally defined 'interests'. On this basis, positivist approaches proceed by examining the linkages between such components in order to discern the operation of general laws, and to produce a systematised account of the various causal mechanisms believed to be at work. Yet while this enables a functioning theoretical model of policy-making behaviour to be constructed, the key problem with 
this methodology is that it treats the observable range of social components in an ahistorical, reified, and taken-for-granted manner, as prima facie given facts of life. This therefore provides no means of explaining why social reality should have assumed this particular form in the first place, offers no means of accounting for the social origins of the various components on which analyses are based, and is subsequently unable to conceptualise the underlying formative relations that exist between those components and the wider pattern of social organisation. The end result is that the rational choice, the country characteristics, and the interest group approaches are all unable to grasp the fundamental constraints that are imposed upon the policy-making process by the compositional form of society itself.

One way of overcoming these difficulties is through the use of an 'open Marxist' methodology. In contrast to more traditional interpretations of Marx which posit a social world made up of reified and deterministically conditioned structures, this 'open' stream within Marxist thinking seeks to recover the original Marxian conception of social reality as an organic process of development that is constituted by the centrality of class, and by the indeterminacy of class struggle. The key advantage this offers in relation to conventional approaches to exchange rate policy-making, is that it places the question of 'social form' at the forefront of the analysis. Instead of starting with the separate components of social reality and with the causal linkages between them, an open Marxist approach views social reality itself as an integral whole, and seeks to understand how and in what way its various constituent parts are derived from, and related to, its underlying formative processes. This provides a framework for analysing political and economic developments that is rooted in a wider social context than that which is provided by more conventional theoretical perspectives (on ‘open Marxism’ see for example Bonefeld et al 1992, 1995; Burnham 1994).

\section{Social form and capitalist production}

An open Marxist analysis begins by drawing a distinction between the appearance and the essence of social reality. In contrast to the immediate perception of the social world as a collection of separate and autonomous 'components' or 'things' imbued with an inherent and objectified existence in-and-of-themselves, these various constituents are instead conceptualised as merely the diverse and multifarious 'theoretical reflections', or the 'phenomenal forms', that are assumed by social relations determined in the process of production. What therefore appears on the surface to be a myriad of independent and externally connected entities is therefore, in essence, a series of internally related phenomena bound together and constituted by the same set of underlying social relations. In ontological terms then, the 'open Marxist' view of social reality is that of a diversity in form marked by a fundamental unity in content (see Marx 1973).

According to Marx, the most fundamental characteristic of these social relations throughout the vast majority of human history has been their division along class lines. One class (or alliance of classes in pre-capitalist social formations) has repeatedly managed to exploit another class (or classes) for their own material benefit by gaining and retaining control over the means of production, and by using this to force an unremunerated extraction of surplus labour. A subordinate class, however, does not simply accept its position in the social order. Rather, the existence of class exploitation also gives rise to resistance, and hence to 'class struggle'. In contrast to more traditional understandings of the term, from an open Marxist viewpoint this is not something which is understood in terms of consciously directed political action, and nor is it conceived as the occasional and one-sided outburst of open and direct resistance by workers. Instead, class struggle 
is seen as a two-way process, as the ongoing resistance to exploitation by the labouring class on the one hand, and as the ongoing efforts of the dominant class to impose and maintain it on the other. As such, the outcome of class struggle is by no means certain. While it is commonly understood by more deterministic conceptions to refer to the inevitable demise of capitalism amidst a proletarian revolution, on a more open reading class struggle is seen as a process with no fixed lines of development, and as something which is inherently fluid and open-ended. Conceived in this way, the centrality of class to the process of social production thus means that the nature and development of the relations of production, and hence the nature and development of the social forms that they assume, are understood as being conditioned by their class character, and by the inherent struggle that this entails. In short, the various observable 'components' of which social reality is comprised are conceptualised as merely the variegated forms that are assumed by the development of class struggle (see Marx 1991, p.927; Bonefeld et al 1995, p.20).

In capitalist society, the means of containing and reproducing these class relations is achieved through the mechanism of the 'value form'. This inheres in the fact that the ordering principle governing the capitalist mode of production, and the key feature distinguishing it from other forms of social organisation, is the production of commodities for the sole point and purpose of exchange. As a result, production in a capitalist society is undertaken by independent and autonomous agents without reference to any social plan or design, and the social connection between its members is only revealed in an indirect manner through the exchange of commodities on the basis of their value. In turn, this is determined by the productivity of labour, which is expressed as the average amount of socially necessary labour time that a commodity takes to produce (Marx 1990, 1992; Rubin 1975). The concept of 'value' then, provides the key for unlocking the internal dynamics of capitalist society itself. In its technical form, this is described by Marx as the 'circuit of capital', which is generically written as the formula: $\mathrm{M}-\mathrm{C} \ldots \mathrm{P}(\mathrm{lp}-\mathrm{mp}) \ldots \mathrm{C}$ '-M'. In the first phase, $\mathrm{M}-\mathrm{C}$, the owner of money capital (M), buys the commodities (C) of labour-power (lp) and means of production (mp) on the open market. In the second phase, the production process, these are put together to function as productive capital $(\mathrm{P})$. Here, through the unequal provisions of the labour contract the capitalist is able to compel the worker to provide their labour power for a greater length of time than that represented by the amount of wages received in remuneration, thereby enabling them to extract a volume of unpaid labour time which is embodied in the commodities produced $\left(C^{\prime}\right)$ as 'surplus value'. In the final phase, C'-M', this expanded sum of value in the form of commodities is thrown onto the market for sale in order to be converted into a sum of money greater than that with which the capitalist initially started (M'). Following this, the whole process is then repeated, ideally on a progressively larger scale so as to facilitate ever greater levels of capital accumulation (see Marx 1992, Chs.1-4).

The necessity for capital to ceaselessly expand in this fashion is driven by the competitive pressures that are inherent to capitalism itself. Since an individual capital can gather up a greater mass of surplus value and obtain a higher rate of profit by increasing the exploitation of its workforce through a restructuring of its means and methods of production, the process of capital accumulation generates continual changes in the social productivity of labour, and hence in the respective values of the commodities that are produced. Ultimately, this forces the generalisation of more 'efficient' methods and practices, as those capitals that fail to keep pace with such developments experience declining profitability and eventual bankruptcy, as rising unemployment intensifies the pressures on employed labour and undermines its ability to resist re-organisation, 
and as firms that are best positioned to adjust and to weather such changes acquire an ever higher share of the market. In this way, by eliminating capitals that fail to continually increase their exploitation of labour in terms of their output of surplus value, the mechanism of the 'value form' (namely the internal dynamics of social relations based on commodity exchange) transmits and enforces the competitive discipline of capitalist production to all individual capitals, thereby helping to ensure the continued profitability of capital as a whole, and therein helping to maintain its continued class domination over labour.

This process however does not proceed smoothly but is vulnerable to disturbances deriving from the unstable class-based foundations of capitalist society. One systemic problem is that the objective desire for an ever-expanding accumulation of surplus value creates a tendency towards commodity overproduction, creating more value than can be absorbed by the market at a price yielding a sufficient rate of profit, and leading to periodic economic and political crises (see Marx 1954). On a more day-to-day basis however, a further problem resides in the dependency of capital itself upon several factors without which it cannot function. These include the provision of an apparently neutral legal framework for upholding property rights, a steady supply of appropriately skilled and disciplined human labour power for exploitation, and a relatively stable currency in order to mediate the exchange of commodities and to provide a stable measure of value in the form of price. In order to fully understand how these various factors are ensured, requires an examination of the capitalist state (de Brunhoff 1978; Marx 1991, pp.472-3; 1992, p.156).

\section{The capitalist state and governing strategies}

On first impressions, the outward appearance of the capitalist state is that of a neutral 'public' sphere of political activity that is distinct and autonomous from the 'private' sphere of economic relations contained within civil society. Conventionally understood as an impartial arbiter whose role it is to discriminate between competing particular interests in order to act in the 'national' or 'general' interest' for the benefit of all its citizens, from an open Marxist perspective such an appearance is deemed to be illusory. Instead, the capitalist state is seen to be a product of the longdrawn class struggles that led to the disintegration of feudal society and to the accompanying emergence of capitalist society during the sixteenth century. By effectively wielding their control over the means of production, the ascendant bourgeoisie were able to reconstruct the old feudal order in accordance with their trading and commercial interests, and to thereby recast the form of the state so as to uphold the legal sanctity of private property. In contrast to the old feudal state form, which was characterised by the fusion of political and economic life and by directly visible relations of exploitation, the capitalist form of the state was now predicated upon an institutional delineation of the social world into separate and distinct 'public' and 'private' spheres, and upon the indirectly coercive mechanisms of the 'free' market.

From an open Marxist perspective then, the capitalist state is not seen as a dispassionate entity that is separate from society, but is instead conceived as an intrinsic element of the capitalist social system itself, as the 'political' counterpart to the 'economic' process of production. As an integral aspect of capitalist society, the behaviour of the state is fundamentally constrained within the limits that are imposed by its class composition. In particular, this compels the state to take continual action in order to regulate class struggle, to address the various crises that result from the instability of capitalist society, and to maintain the process of capital accumulation as a whole. A full analysis of the limits of state behaviour, however, also requires an international perspective. 
The prosperity and stability of the state fundamentally rests upon the successful integration of the domestic economy (or the 'national' circuit of capital) into the international circuit of capital, and thus conversely, upon the prosperity and stability of the world circuit itself. As such, each state must simultaneously provide globally favourable conditions for capital accumulation within its borders (or capital will gravitate towards more profitable climes, provoking economic difficulties and associated political crises), and must strive to ensure the well-being of international capitalist relations as a whole. While states are forced to compete with each other for globally mobile capital, they are also forced to co-operate in order to ensure the successful flow of the circuit of capital both domestically and internationally (Barker 1978; de Brunhoff 1978).

A central requirement for states as they seek to achieve these aims is to ensure the international convertibility of their currencies. This is needed in order to integrate the various national components of the global circuit itself, and to facilitate the flow of international trade and payments that are necessary for domestic growth and stability. The manner by which this convertibility takes place is determined by the exchange rate regime. The particular form of this regime conditions the means through which the dynamics and pressures of the global economy are transmitted to the domestic circuit of capital, and vice versa, through which the international influence of the domestic circuit itself is felt. In this way, just as the mechanism of the value form transmits the competitive discipline of capitalist relations to individual capitals, so it also transmits global capitalist discipline to national states through the international system of exchange rates, by forcing states to pursue economic policies that are conducive to maintaining confidence in their currencies.

While the overarching objective for governments of capitalist states is to therefore ensure that national and global conditions are conducive to the progressive growth of capital accumulation, this remit is also punctuated by more subjective aims and ambitions. Generically, these can be conceived as a series of 'high political' goals such as retaining office, enhancing departmental and party political status, and strengthening personal authority, influence, and prestige. With this in mind, state managers can be usefully portrayed as seeking to develop a 'governing strategy' in order to help them achieve their various aims. This will identify the key problems that are faced, and will provide a plan for their resolution based on the wider cultural, institutional, and ideological context in which they are set. While the development of a governing strategy may at times be a fractious process, and while key officials may not be in complete agreement as to its content (indeed, not all may even be involved in its formulation), its construction will nonetheless provide the state authorities with a broad guide to the political and economic terrain in which they are operating, and will offer some means of charting a safe course across it. In general terms, a particularly useful strategy is to seek to establish and maintain a degree of 'governing autonomy' from social and political pressures. The more space and freedom that officials have to implement their key policy tasks, the higher the likelihood is that these will be implemented in a competent fashion, and hence the greater is the prospect that their political and economic aims will be achieved. The central challenge for key state managers, therefore, is to develop and implement a governing strategy that will enable them to contain class struggle, to ensure favourable conditions for capital accumulation, and to attain a sufficient degree of autonomy with which to engage in high political activity (on the notion of 'statecraft' see Bulpitt 1983, Chs.2-4; Buller 1999).

While the state authorities may at times find it desirable or even necessary to pursue a governing strategy based on the directly visible involvement of the state in economic affairs (such as the 
'Keynesian' mode of economic management), such an approach contains inherent dangers. In particular, openly visible state intervention can lead to the politicisation of issues that have previously been regarded as being of a purely 'economic' character (such as wage levels and working conditions), and can thereby lead to growing demands and pressures over these issues being directed at the state itself. Moreover, such politicisation also contains the risk that a crisis in the 'economic' sphere will necessitate overt state action in favour of capital in order to secure continued accumulation, and that this will expose the class character of the state by openly contravening its claim to act in the general interest. A key danger of a governing strategy based on a politicised mode of economic policy-making then, is that this can serve to aggravate class unrest, and may even result in a wholesale crisis of political authority (Fine 1979, p.178; Bonefeld and Burnham 1998).

Given these risks, a more productive approach for state managers is to therefore try and remove key areas of economic policy-making from the realm of political accountability through a governing strategy of 'depoliticisation'. By relocating core aspects of economic policy-making away from the discretionary control of the state, and by placing them instead under the control of independent and ostensibly 'non-political' bodies and/or policy rules, it is possible for key state officials to distance themselves from the policy-making process. This will enable them to retain a degree of 'armslength' control over key economic policy issues while simultaneously disclaiming responsibility, and hence accountability, for such matters. A further advantage of a depoliticisation strategy is that a credible relinquishing of discretionary control can serve to 'lock-in' the future direction of economic policy and to thereby confine the expectations (and hence the behaviour) of both capital and labour within the limits set by the policy regime. This ability to constrain expectations is further increased if the set of rules and bodies to which economic policy-making tasks are reassigned are themselves constituted 'externally' as part of an international system. This will enable the authorities to present the regime as being bound up with wider political and economic issues, and will increase the costs of regime change, thereby enhancing its credibility and hence its depoliticising effects. In sum, by imposing an effective discipline on national economic relations and by furnishing officials with a means of insulating themselves from the adverse political and social effects of this process, a governing strategy of depoliticisation can leave key state managers better placed to enforce policies designed to regulate class struggle, facilitate the accumulation of capital, and secure a greater degree of freedom for the pursuit of high political goals (on the subject of depoliticisation see Burnham 1999, 2001).

\section{Exchange rate policy-making}

The question of exchange rate policy-making needs to be examined against this background of economic policy-making in general, and needs to be understood in relation to the particular aims of the governing strategy that is being pursued by key state managers. Of the various exchange rate regimes that are available, a 'floating' regime in which the value of the national currency is free to fluctuate according to the market level of supply and demand can prove to be useful should the authorities wish to pursue a governing strategy of depoliticisation based on domestic policy rules or non-political bodies such as an inflation target and/or central bank independence. One major attraction of a floating regime is that this can provide officials with a degree of flexibility and adaptability that is not available under more restrictive systems, and can allow state managers to alter or abandon their strategy should the policy rule prove to be unsuccessful, with less risk of 
incurring the kind of repercussions that may follow the breaking of international commitments. A notable example of such an approach was evident in Britain's adoption of a floating pound coupled with an inflation target following its ignoble exit from the Exchange Rate Mechanism in 1992.

The flexibility afforded by a floating regime can thus provide officials with a useful 'safety valve', helping to insulate the national circuit of capital from the competitive pressures of the global economy by permitting adverse developments such as rising inflation or declining productivity to be offset through a movement in the exchange rate. A loss of competitiveness for example will, ceteris paribus, lead to a decline in exports and a fall in the value of the national currency which will itself help to redress the economic balance by reducing export prices. Conversely, while this will help to protect officials from the failure of a domestic policy rule, movements in the exchange rate can also help to support such a strategy. A rise in the exchange rate, for instance, can help to buttress an anti-inflationary commitment by imposing additional deflationary pressure on the economy through higher export prices, as demonstrated for instance by the US policy of 'benign neglect' towards an appreciating dollar during the mid-1980s. Furthermore, in certain circumstances a fall (or even the threat of a fall) in the exchange rate can also have a similar effect since higher import prices, a rise in the external debt burden, and the prospect of rising inflation can lead to an increase in production costs, a rise in unemployment, and justify the imposition of tighter fiscal and monetary measures. This provided the basis for Britain's aborted 'operation ROBOT' scheme of the early 1950s, which aimed to break the postwar class settlement and to impose greater competitive discipline on the British economy via a shift to a floating exchange rate and a large depreciation in the value of the pound (see Bulpitt and Burnham 1999).

A floating exchange rate regime, however, is not without its disadvantages. One problem is that a domestically based policy rule may lack credibility, and may therefore prove to be ineffective due to the relative ease with which it can be broken or revoked compared to an international commitment. This may be compounded by the fact that the depoliticising effects of a domestic rule may also wear thin should economic conditions deteriorate significantly. In the event that the rule itself should come to be seen as a key source of difficulties then this can leave officials exposed to criticism and can pave the way for a re-politicisation of economic conditions and policy-making, thus putting the governing authorities under increasing pressure. This proved to be the case in Britain following the disintegration of the government's monetarist strategy amidst a huge recession, a dramatic rise in unemployment, and mounting class unrest. Moreover, while the ability to change or abandon the policy rule will still remain an option, there can be no guarantee that the adoption of a new rule will prove to be a success, and in fact the reverse may even be the case, since state managers may now have acquired a reputation for being manipulative, deceitful, and opportunistic.

Further still, while a floating exchange rate can help to ensure macroeconomic stability by offsetting changes in national economic performance through changes in the value of the currency, in other circumstances this regime can prove to be destabilising. Fluctuations in the exchange rate that are unwarranted by national economic 'fundamentals', such as levels of economic competitiveness and productivity, but that are the result of factors such as changes in market sentiment or shifting economic conditions elsewhere, may run counter to, and may even undermine domestic policy commitments. Exchange rate uncertainty and instability may adversely affect the integration of the national economy into the international circuit of capital (a general problem for many Western capitalist nations following the collapse of the Bretton Woods system during the 
early 1970s), an excessive rise in the exchange rate may impose an excessive deflationary strain on the economy (as seen in Britain and Japan during the first and latter halves of the 1980s respectively), while the inflationary pressures resulting from an undue decline in the rate can also erode the effectiveness of domestic economic policies (as demonstrated for example by events in the United States towards the end of the 1980s).

To an extent, some of these problems can be overcome by utilising a 'managed' exchange rate regime in which the authorities undertake to limit any excessively large or rapid fluctuations in the value of the currency. The advantage of this practice, known as 'leaning against the wind', is that it can offer greater stability than a floating regime, and, by allowing the rate to slowly adjust to any medium- to long-term changes in underlying economic conditions, can also enable the authorities to retain the benefits of policy flexibility and the credibility of continuing with a domestic policy rule. Such an approach was successfully utilised by Britain during the 1930s, as policymakers sought to avoid any dramatic changes in the value of the pound following the abandonment of the gold standard, though also sought to displace political responsibility for economic conditions via a series of depoliticising measures such as maintaining de facto central bank independence (see Kettell 2004, Ch.6).

Should this combination of a floating or managed exchange rate and a domestic policy rule prove to be an impractical or undesirable means of pursuing a strategy of depoliticisation however, another possible approach is to utilise a floating or managed regime as part of a directly politicised mode of economic policy management. By providing the authorities with the discretionary freedom to pursue overtly political objectives such as high employment and economic growth, this approach may be particularly attractive should officials wish to ease any economic or political difficulties (especially those closely associated with the breakdown of a policy rule), by allowing them to adopt policies designed to stimulate an economic recovery. In addition, this strategy also leaves open the possibility that the authorities can seek to gain an economic advantage over competitor nations by deliberately holding down the level of the exchange rate in order to encourage export growth and restrict imports, a key feature, for example, of the American governing strategy pursued during the 1930s. Further still, the pursuit of a politicised governing strategy will also make it easier for the authorities to claim the plaudits for any success, since no credit need now be given to international parties or to non-political domestic institutions.

Nevertheless, despite promising much, the advantages of a floating or managed exchange rate regime may in fact prove to be more apparent than real. Despite the lure of freedom and flexibility, state managers are in reality unable to ignore or avoid large movements in the exchange rate since these will have a direct and potentially severe impact on the national economy, and since the volume of funds available to the foreign exchange markets far exceeds that which can be mustered by any national state for the purposes of intervention. In contrast to a floating or a managed regime then, the authorities may choose to adopt a 'fixed' exchange rate regime (in which the value of the national currency is held at or around a specific value), as part of a politicised governing strategy. Although this will require that certain provisions are made in order that the exchange rate can be periodically altered in response to changing national economic and social conditions (such as those provided by the postwar Bretton Woods system), a fixed exchange rate can nonetheless help to provide the benefits of even greater economic certainty and stability.

Despite this though, utilising a 'fixed-but-adjustable' regime as part of a politicised governing strategy also faces several problems. Since the level of the exchange rate will now be determined by 
the authorities themselves, one danger is that the chosen value may be too high or too low in relation to national economic conditions, and that the commitment to maintain the rate may therefore lack credibility. Indeed, since a politicised strategy is likely to be adopted precisely because the authorities wish to be free to respond to domestic pressures, the prospect of political or economic difficulties is itself likely to generate speculative pressures that may destabilise the regime. This was amply demonstrated by the events surrounding the infamous devaluation of sterling in 1967 amidst a sharp loss of international confidence in the ability of Britain's Labour government to maintain a sound economic policy position and to resist rising demands for everhigher levels of public spending. A more general problem, however, is that while a politicised mode of economic policy management can allow the authorities to take all the credit for policy successes, such an approach will of-itself also subject them to growing social pressures and render them directly and visibly responsible for economic conditions, thereby curtailing their freedom of high political manoeuvre. Given the unstable and inherently crisis-ridden nature of capitalist society then, deliberately politicising economic conditions and policy-making therefore remains a high risk strategy.

A more useful approach for the governing authorities is to therefore utilise a fixed exchange rate regime as part of a strategy of depoliticisation. By committing themselves to maintain a fixed exchange rate with provision for realignment only in the most exceptional of circumstances, the state authorities can impose a more credible constraint on their discretionary freedom than can be achieved by using either a fixed-but-adjustable regime or a domestically based policy rule. Reneging on this commitment can now prove to be more costly in terms of international as well as domestic repercussions, while the future direction of economic policy as a whole will now be 'locked-in', since this will need to be geared towards ensuring the maintenance of the chosen exchange rate. In particular, this can help to ensure that national economic conditions remain internationally competitive, and can expose them more forcefully to the global discipline of the value form, since any decline in competitiveness will now require the imposition of deflationary measures in order to prevent a fall in the value of the currency. Moreover, although it contains the risk of excessive deflation, the pressures of a fixed exchange rate can be enhanced by setting the value of the currency at a relatively high level (a strategy pursued by the British authorities in the return to the gold standard in 1925, and in joining the Exchange Rate Mechanism in 1990), and while the possibility of setting the exchange rate at a relatively undervalued level in order to gain a competitive export advantage remains, such an approach runs the risk that rising levels of inflation will destabilise and undermine the regime, with all the attendant economic and political dangers that this involves.

In addition to these economic effects, a fixed exchange rate regime can also offer useful political benefits. One particular advantage is the ability to shield state managers from the unpalatable social and political effects that may result from the economic constraints imposed by the regime. By enabling the effects and the responsibility for tough economic policies to be presented as having derived from the regime itself, rather than from the discretionary behaviour of state officials, a credible fixed regime can thereby make it easier for the authorities to disclaim accountability for key economic policy decisions, and can even help to remove such issues themselves from the political agenda since the possibility for change will no longer be visibly open. Further still, these economic and political advantages are both likely to be further enhanced if the regime itself is embedded in a wider set of international commitments and obligations (such as the 
process of European integration), since this will further legitimise its constraints, and will enable them to be further presented as emanating safely 'from outside' (see Burnham 1999).

Despite these benefits however, a fixed exchange rate regime is also not without its difficulties. The ability to gain a competitive advantage through an undervalued exchange rate, or to enforce greater economic discipline through the use of a relatively high exchange rate is, by definition, not open to all nations at the same time and is thus dependent on the various strategies that are being pursued by other countries. Moreover, such moves may themselves create or exacerbate instability in the national and international circuits of capital, and may therefore prove to be counterproductive (such as the French strategy of rejoining the gold standard at an undervalued exchange rate during the mid-1920s).

A more general problem associated with a fixed regime though, is its lack of flexibility. By committing themselves to maintain a specific value for the national currency, state managers run the risk that changing economic circumstances, either nationally or in the state(s) to which the currency has been fixed, can lead to the development of a 'internal-external' conflict between the aims of maintaining the exchange rate and the aims of ameliorating social and political pressures through a more relaxed economic policy stance. The danger here is that if such a conflict is allowed to go unchecked, then this can eventually lead to the growth of speculative pressures against the currency as questions about the ability of the authorities to continue defending the rate begin to rise, and can ultimately lead to the collapse of the regime itself. Such an eventuality was notably evident during the currency crises which engulfed the European Monetary System during the early 1990s, and in the spread of currency instability throughout Asian and Latin American countries during the latter half of the decade, in which several nations were forced to abandon their respective fixed exchange rate regimes in the face of a speculative onslaught from the international financial markets.

One way of overcoming some of these problems is through a process of complete monetary union, such as that which was finally achieved by European Union states in 1999. This can strengthen both the credibility and the discipline of a fixed exchange rate regime by completely removing the possibility of any future change in the value of the national currency, and can further strengthen its depoliticising properties, since key economic policy issues will now be even further removed from the sphere of democratic control and accountability. Despite these benefits however, a strategy of monetary union also contains its own dangers. The complete lack of flexibility now means that any deterioration in national economic conditions cannot be alleviated through a change in the exchange rate or through the adoption of a more relaxed economic policy stance, while in the event that the national economy itself should fail to respond to the constraints of the regime then the risk of social and political tensions will rise, as will the ultimate danger that the legitimacy of the exchange rate regime itself could be undermined.

\section{Concluding remarks}

The above examination has shown that while the subject of exchange rate policy-making is of crucial importance for an understanding of the relationship between the national state and the global economy, conventional means of analysis are inherently problematic. Most notably, the positivist ontology that underpins such approaches precludes any consideration of the fundamental question of 'social form', and is thus unable to conceptualise the wider social context within which the policy-making process takes place. One way of overcoming this difficulty is by utilising an 
'open Marxist' methodology. While the main task for positivist approaches is to establish causal linkages between the discrete, autonomous, and objectified components of the social world, an open Marxist perspective views such phenomena as integral parts of an organic social whole, and seeks to understand how and in what way they are derived from, and related to, this totality of social relations. More specifically, an open Marxist approach conceptualises the observable constituents of social reality as the theoretical offspring of relations that are established during a process of production that is itself characterised by the development of an indeterminate class struggle. By revealing the social constitution of these surface components, an open Marxist approach enables a view of exchange rate policy-making which is radically different from those presented by conventional analyses.

On this basis, exchange rate policy is not seen as the result of abstract interactions between equally rational public and private actors, as deriving from national structural characteristics, or as the outcome of interest group pressures. Instead, it is understood as a component part of a wider governing strategy, which is made with a view to providing favourable conditions for capital accumulation, to containing and regulating class relations, and for ensuring a sufficient degree of high political freedom for the governing authorities. Given the unstable and crisis-ridden nature of capitalist society, however, no single exchange rate regime is capable of fulfilling these aims and ambitions at all times and in all circumstances. Instead, state managers are forced to shift between regimes in response to changing political and economic conditions in order to achieve their policy objectives. The key advantage of analysing such decisions from an open Marxist perspective then, is that this highlights the way in which such policy choices are conditioned by the shifting class dynamics of capitalist society. As such, this provides a new theoretical foundation both for analysing the subject of exchange rate policy-making itself, and for asserting its centrality to an understanding of high level economic and political developments. If successful, a hitherto marginal area of study can become open in more ways than one.

\section{Bibliography}

Aghevli, B, B., and Montiel, P, J., (1991), 'Exchange rate policies in developing countries', in Emil-Maria Claassen, (ed)., Exchange Rate Policies in Developing and Post-Socialist Countries, International Centre for Economic Growth, California.

Argy, V., (1982), Exchange Rate Management in Theory and Practice, Princeton Studies in International Finance. No.50.

Argy, V., (1990), 'Choice of exchange rate regime for a smaller economy: a survey of some key issues', in V. Argy., and P. De Grauwe., (eds.), Choosing An Exchange Rate Regime: The Challenge For Smaller Industrial Countries, International Monetary Fund, Washington DC.

Barker, C., (1978), 'A note on the theory of capitalist states', Capital and Class. No.4.

Bonefeld, W., Gunn, R., and Psychopedis, K., (1992), (eds.), Open Marxism. Vol. I: Dialectics and History, Pluto Press, London.

Bonefeld, W., Brown, A., and Burnham, P., (1995), A Major Crisis?: The Politics of Economic Policy in Britain in the 1990s, Dartmouth Publishing Co. Ltd., Aldershot.

Bonefeld, W., and Burnham, P., (1998), 'The politics of counter-inflationary credibility in Britain 1990-94', Review of Radical Political Economics, 30(1).

Bordo, M, D., and Kydland, F, E., (1995), 'The gold standard as a rule: an essay in exploration', Explorations in Economic History 32. 
Buller, J., (1999), 'A critical appraisal of the statecraft interpretation', Public Administration. 77 (4).

Bulpitt, J., (1983), Territory and Power in the United Kingdom : An Interpretation, Manchester University Press, Manchester.

Bulpitt, J., and Burnham, P., (1999), 'Operation Robot and the British political economy in the early-1950s: the politics of market strategies', Contemporary British History 13(1).

Burnham, P., (1994), 'Open Marxism and vulgar international political economy', Review of International Political Economy 1(2).

Burnham, P., (1999), 'The politics of economic management in the 1990s', New Political Economy, 4(1).

Burnham, P., (2001), 'New Labour and the politics of depoliticisation', British Journal of Politics and International Relations. 3(2).

Caramazza, F., and Aziz, J., (1998), 'Fixed or flexible? getting the exchange rate right in the 1990s', Economic Issues 13, International Monetary Fund, Washington D.C.

Cuckierman, A., and Meltzer, A, H., (1986), 'A positive theory of discretionary policy, the cost of democratic government and the benefits of a constitution', Economic Inquiry, Vol.XXIV.

De Brunhoff, S., (1978), The State, Capital and Economic Policy, Pluto Press Ltd., London.

Edwards, S., (1996), 'The determinants of the choice between fixed and flexible exchange-rate regimes', NBER Working Paper 5756, National Bureau of Economic Research, Cambridge, Massachusetts.

Fine, B., (1979), 'World economic crisis and inflation: what bourgeois economics says and why it is wrong', in F. Green, and P. Nore, (eds.), Issues in Political Economy: A Critical Approach, MacMillan, London.

Frieden, J, A., (1998), 'The political economy of European exchange rates: an empirical assessment', Working Paper. Harvard University, USA.

Frieden, J, A., (2000), 'Exchange rate politics', in J. A. Frieden and D. A. Lake, (eds.), International Political Economy: Perspectives on Power and Wealth. Fourth Edition. St. Martins. USA.

Hamada, K., (1987), The Political Economy of Monetary Interdependence, The MIT Press, London.

Havrilevsky, T., (1994), 'The political economy of monetary policy', European Journal of Political Economy, 10.

Hefeker, C., (1997), Interest Groups and Monetary Integration: The Political Economy of Exchange Regime Choice, Westview Press, Oxford.

Helpman, E., (1981), 'An exploration in the theory of exchange rate regimes', Journal of Political Economy. 89(5).

Honkapohja, J., and Pikkarainen, P., (1994), 'Country characteristics and the choice of exchange rate regime: are mini-skirts followed by maxis?, in J. Ákerholm and A. Giovannini, (eds.), Exchange Rate Policies in the Nordic Countries, Centre for Economic Policy Research, London.

Kettell, S., (2004), The Political Economy of Exchange Rate Policy-Making : From the Gold Standard to the Euro, Palgrave, London.

Marx, K., (1954), Theories of Surplus Value, Lawrence \& Wishart, London. 
Marx, K., (1973), Grundrisse : Foundations of the Critique of Political Economy, Penguin Books Ltd., Middlesex.

Marx, K., (1990), Capital : A Critique of Political Economy Volume I, Penguin, London.

Marx, K., (1991), Capital : A Critique of Political Economy Volume III, Penguin, London.

Marx, K., (1992), Capital : A Critique of Political Economy Volume II, Penguin, London.

Milesi-Ferretti, G, M., (1995), 'The disadvantage of tying their hands: on the political economy of policy commitments', The Economic Journal. 105.

Miller, M., Eichengreen, B., and Portes, R., (1989), (eds.), Blueprints for Exchange Rate Management, Academic Press Ltd., London.

Oatley, T, H., (1997), Monetary Politics : Exchange Rate Co-Operation in the European Union, University of Michigan Press, USA.

Rubin, I, I., (1975), Essays on Marx's Theory of Value, Black Rose Books, Quebec.

Savvides, A., (1990), 'Real exchange rate variability and the choice of exchange rate regime by developing countries', Journal of International Money and Finance, 9.

Vaubel, R., (1990), 'Currency competition and European monetary integration', The Economic Journal, 100.

Walsh, J, I., (1994), 'Politics and exchange rates: Britain, France, Italy, and the negotiation of the European monetary system', Journal of Public Policy, 14.

Walsh, J, I., (2000), European Monetary Integration and Domestic Politics : Britain, France, and Italy, Lynne Rienner, London. 